\title{
Wpływ współczesnych migracji terrorystycznych na bezpieczeństwo
}

\section{Wprowadzenie}

Współcześnie próba jednoznacznej i zwięzłej definicji bezpieczeństwa stanowi niemały problem. Doktryna w wielu publikacjach wskazywała na wieloaspektowość tego terminu oraz na liczne czynniki uniemożliwiające sformułowanie jednej definicji. Zasadniczy problem stanowi to, że należy bezwzględnie odnieść się do podmiotu zainteresowania, do jego pozycji, czasu, perspektywy, standardów, a także do norm i kontekstu kulturowego, przy czym wszystkie te przesłanki mają każdorazowo inny charakter ${ }^{1}$. Jakkolwiek rozumiane bezpieczeństwo mimo transformacji w kontekście społecznym, politycznym, ekonomicznym, lub nawet technologicznym, nadal jest elementarną potrzebą każdej jednostki społecznej ${ }^{2}$. Niewątpliwie pojęcie bezpieczeństwa odnosi się do jednostek, ale również takich podmiotów, jak organizacje, wspólnoty czy państwa. Zagadnienie bezpieczeństwa można rozpatrywać przynajmniej w dwóch aspektach: jako bezpieczeństwo wewnętrzne, ale i bezpieczeństwo zewnętrzne. Niniejszy artykuł koncentruje się na generalnym znaczeniu i istocie terminu bezpieczeństwo, z pominięciem powyższego podziału.

* Patryk Roger Zabrocki, mgr, Uniwersytet Warmińsko-Mazurski w Olsztynie, e-mail: patryk.zabrocki@gmail.com, https://orcid.org/0000-0001-5345-7854.

${ }^{1}$ S. Freud, Das Unbehagen in der Kultur, w: Kulturtheoretissche Schriften, Frankfurt a. Main 1974, s. 243.

2 S. Sulowski, W poszukiwaniu definicji bezpieczeństwa wewnętrznego, „Przegląd Bezpieczeństwa Wewnętrznego" 2009, nr 1, s. 10-13. 
Bezpieczeństwo jest gwarantem realizacji niezbędnych do życia potrzeb prawidłowej egzystencji, rozwoju, wolności, przyrodzonej godności ludzkiej. Czy jednak dana podstawowa wartość współcześnie jest określona w miarę rozsądnie? Gdzie znajdują się granice bezpieczeństwa, a gdzie nienaruszalnych praw i wolności obywatelskich wskazanych w licznych aktach prawnych oraz traktatach? Droga do odnalezienia uniwersalnej definicji w danym zakresie nie jest kwestią sporu w doktrynie. Ustalenie pojęcia bezpieczeństwa jest wyłącznie kwestią polityki, która wynika z działań obecnie sprawujących władzę w państwie lub większości decyzyjnej we wspólnotach. To od nich zależy, co w danym momencie jest istotne dla dobra obywateli i jaka strategia będzie właściwa. Na powyższe ma wpływ integracja wspólnotowa o bezspornie politycznym charakterze, ale także proces określany jako globalizacja.

Globalizacja jest procesem, w którym widoczny jest istotny wpływ działania jednej strony świata (decyzje i związane $z$ nimi wydarzenia) na drugą ${ }^{3}$. Jest procesem, z którego najwięcej korzyści osiąga dziś międzynarodowy terroryzm, a przestępczość terrorystyczna nie jest ograniczona przez bariery kulturowe czy językowe. Globalizacja umożliwia organizacjom terrorystycznym pełen dostęp do najnowszego dorobku technologicznego, współczesnych wynalazków. Grupy terrorystyczne w sposób nieskrępowany mogą korzystać z kanałów i systemów finansowych. Efekty globalizacji z czasem mijają, choć w życiu codziennym prowadzą do sporych zmian. W innym kierunku podąża zmiana dotycząca bezpieczeństwa podyktowana globalizacją. Jest to zdecydowanie negatywny kierunek ${ }^{4}$.

Niezbędne do dalszych rozważań jest określenie definicji zjawiska terroryzmu, które także nie jest kwestią ostatecznie zamkniętą. Terroryzm określa się obecnie jako zaplanowane działania wykonywane przez jeden podmiot lub ich zbiór, mające charakter w pełni przemyślany, z założenia zmierzające do zniszczenia, a przede wszystkim nielegalne. Źródłem tych działań mogą być motywy polityczne, religijne, personalne i wiele innych. Zawsze jednak są one skierowane przeciwko określonemu państwu lub innemu podmiotowi międzynarodowemu jego obywatelom, ich mieniu, osobom publicznym i przedstawicielom, instytucjom, infrastrukturom czy symbolom. Dzisiaj do najważniejszych

${ }^{3}$ J. Kis-Bendek, Dzihadizmus, Radikalizmus, Terrorizmus, Budapest 2016, s. 151.

${ }^{4}$ A. Molnar, Travel Documents in Use by Terrorists, „Internal Security" 2019, no. 11(1), s. 133. 
kroków w zakresie przeciwdziałania terroryzmowi w Polsce i wspólnotach, które współtworzy, należy wypracowanie najnowszych, rozwiniętych i kompleksowych przepisów prawnych ${ }^{5}$.

Celem artykułu jest analiza na wybranych przykładach zagadnień związanych z szeroko rozumianą definicją bezpieczeństwa oraz nowoczesną i rozwijającą się migracją terrorystyczną. Nie ulega wątpliwości, że procesowi rozwoju podlegają liczne mechanizmy egzystencji społeczeństw i ich politycznych organizacji. Państwa udoskonalają metody i formy swego funkcjonowania, w tym również w aspekcie bezpieczeństwa, ewolucji podlegają jednak także formy organizacyjne i mechanizmy działania światowego terroryzmu. Dzisiejszy terroryzm znacząco odbiega w swych cechach od pierwotnego wzorca, choć motywy pozostały niezmienne. Nowoczesne technologie, zaawansowana organizacja, wykształcona i profesjonalna kadra etc. wskazują na postępowy i nowoczesny charakter niebezpieczeństwa terrorystycznego na świecie. Wciąż rozwijająca się i zaawansowana migracja jako narzędzie walki z państwami rozwiniętymi oraz wspólnotami międzynarodowymi jest oczywistą konsekwencją.

Celem niniejszego opracowania jest też omówienie przedmiotowego tematu z perspektywy obecnego stanu faktycznego, ale również za pomocą metody krytyki i analizy piśmiennictwa, która pozwoli w pełni zrozumieć kształt, funkcjonowanie i przyczyny błędów dzisiejszych organów bezpieczeństwa. Będzie to miało wpływ na sformułowanie postulatów ewentualnych przyszłych zmian w prawie, dotyczących przede wszystkim praktyki organów bezpieczeństwa.

\section{Pojęcie współczesnego terroryzmu}

Rozwój metod organizatorów zamachów terrorystycznych jest ściśle związany z ewolucją struktur, technik, form funkcjonowania organów odpowiedzialnych za usuwanie tych niebezpieczeństw. W ostatnich dekadach zaobserwowano liczne zmiany technik działań terrorystów. Każdorazowo wskazywano, że łączy się to ze zmianami dotyczącymi motywów i elementów ideologii. Z czasem sprawcy czynów terrorystycznych $\mathrm{w}$ większym stopniu dokonują zamachów z przyczyn religijnych bądź etnicznych. Zmniejszyła się jednak liczba przestępstw

${ }^{5}$ S. Wojciechowski, Terroryzm. Analiza pojęcia, „Przegląd Bezpieczeństwa Wewnętrznego" 2009, nr 1, s. 54-60. 
terrorystycznych z przyczyn ideologii lewicowych. Konieczne jest dalsze studiowanie każdego z zaistniałych przejawów terroryzmu i dostosowywanie metod organów bezpieczeństwa z maksymalnie możliwym wyprzedzeniem w stosunku do rozwoju nowoczesnych metod terrorystów, ze szczególnym uwzględnieniem pobudek sprawców tychże zachowań przestępczych ${ }^{6}$.

Rzeczpospolita Polska oraz Unia Europejska stoją dziś w obliczu wyzwań związanych $\mathrm{z}$ bezpieczeństwem w generalnym jego znaczeniu, ale także ze współczesnymi zagrożeniami związanymi z technologią informacyjną, transportem, handlem, finansami, zdrowiem publicznym, które utrzymują się na stałym poziomie, co skutkować może nowymi zagrożeniami. Świat w nierówny sposób korzysta dziś z pozytywnych efektów globalizacji. Skutkiem tego jest pozytywnie postrzegana przez państwa rozwinięte przepaść społeczna, gospodarcza i polityczna pomiędzy różnymi krajami. Błędem jest uznawanie danej przepaści za właściwą. Różnice między regionami skutkują sprzeciwem wobec danego zjawiska, czego efektem jest m.in. rozwijający się terroryzm. Istniejąca przepaść winna być przesłanką dla rozwiniętej części świata do pomocy i niwelowania różnic, a nie do ich pogłębiania. Regiony rozwijające się lub państwa, które prowadzą nieskuteczną politykę bezpieczeństwa, mogą być idealnym miejscem dla przestępczości zorganizowanej działającej ponad granicami. To może pozwolić organizacjom terrorystycznym na zdobycie silniejszej pozycji mimo ich słabego potencjału, a także zwiększyć problemy z migracją ludzi oraz handlem bronią i narkotykami. Obecnie wskazuje się, że większość przypadków związanych z niewłaściwym wykorzystaniem paszportów lub innych dokumentów powiązana jest z działalnością terrorystyczną. Dokumenty podróży winny być równie ważne i monitorowane jak broń oraz materiały wybuchowe. Podróże winny być rejestrowane, co w znacznym stopniu utrudniałoby terrorystom podróżowanie bez określonego celu, trasy i danych, których nie da się zidentyfikować.

Nie każda z osób o określonych cechach, o których mowa, jest zamieszana w działalność terrorystyczną. Profil terrorysty jest bardzo specyficzny, charakteryzuje się głębokim zaangażowaniem, ekstremizmem oraz bojowością. Cechy i wartości etniczne, religijne oraz kulturowe nie wskazuja, że wszyscy członkowie tych grup są zaangażowani lub

${ }^{6}$ M. Piekarski, Ewolucja taktyki terrorystów po roku 2001, „Przegląd Bezpieczeństwa Wewnętrznego" 2015, nr 13(7), s. 243-254. 
kontaktują się z organizacjami terrorystycznymi. Działalność terrorystyczna od wielu lat zbiera niewinne ofiary na całym świecie i dana praktyka staje się coraz częstsza. Zagrożenie terrorystyczne wzrasta nie tylko w krajach innych kontynentów, ale także w Europie, co jest bardzo niepokojące. Badając temat, nie można wskazywać wyłącznie na odizolowane organizacje terrorystyczne, ponieważ mogą one nawiązywać relacje międzynarodowe $z$ innymi organizacjami o rozbudowanej strukturze. Poszczególne grupy, wspomagając się, tworzą sieć, zapewniają narzędzia i ludzi do swoich przedsięwzięć, przekazują informacje albo zapewniają specjalistyczne szkolenia ${ }^{7}$.

Swoje podróże terroryści ukrywają, używając fałszywych dokumentów tożsamości oraz dokumentów podróży, lub też ich terminowo wystawianych odpowiedników. Dokumenty nabyte w sposób zabroniony, a następnie użyte, dają możliwość przejścia przez granicę i przeprowadzenia ataku albo serii ataków terrorystycznych. Według sprawozdań Europejskiego Urzędu Policji (EUROPOL) nie ma solidnych dowodów na to, że terroryści wykorzystują regularnie napływ imigrantów czy uchodźców - osób, które musiały opuścić teren, na którym mieszkały, ze względu na różnego typu prześladowania. Imigranci to osoby, które przybywają do nowego kraju, innego niż kraj ich pochodzenia, w związku z czym każdy uchodźca to imigrant, lecz nie każdy imigrant to uchodźca. Uchodźstwo jest statusem prawnym nabytym przez imigranta w miejscu docelowym, zgodnie z procedurą wewnętrzną państwa przyjmującego. Wykorzystując najnowsze technologie, dżihadyści mogą przybywać do Europy bez uprzedzenia i w sposób nieskrępowany. Nie ma jednak wątpliwości, że nieliczni terroryści mogą udawać uchodźców, czyli tych najbardziej potrzebujących i prześladowanych, tym samym oddziałując na emocje funkcjonariuszy podmiotów kontrolujących nielegalną migrację. Ci terroryści, którzy wykorzystują fale migracyjne, z zasady są wyłącznie członkami o niskim stopniu w organizacji, podczas gdy wysoko usytuowani członkowie grupy, o zaawansowanym wyszkoleniu, mogą mieć prawdziwe lub perfekcyjnie sfałszowane dokumenty i przyjeżdżać do wybranych krajów w bezpieczny i spokojny sposób. Nielegalne podróżowanie jest związane z możliwością zatrzymania lub wydalenia. Wykorzystanie fali migracyjnej ujawnia bezsilność organizacji bojowych, wskazuje na ich słabość i problemy ze współczesnymi zabezpieczeniami. Ukazuje jednak także silną determinację

${ }^{7}$ A. Vajda, Kuzdelem a terrorizmus ellen, Budapest 2003, s. 5-6. 
terrorystów do osiągnięcia z góry założonego celu i prowadzenia wojny ze znienawidzonym „imperializmem krajów Zachodu”.

EUROPOL jako międzynarodowy organ ścigania w państwach wspólnoty europejskiej może wspierać organy państw członkowskich, takich jak polska Policja ${ }^{9}$ i Żandarmeria Wojskowa ${ }^{10}$, w zwalczaniu przestępczości międzynarodowej oraz terrorystycznej. Zapewnia wsparcie dla działań związanych z egzekwowaniem prawa, funkcjonuje jako platforma informacyjna dla przestępstw i odgrywa istotną rolę w siedzibie głównej Unii Europejskiej, posiadając wiedzę specjalistyczną w zakresie egzekwowania prawa ${ }^{11}$.

\section{Nowoczesna migracja terrorystyczna}

Migracja osób należących do organizacji terrorystycznych jest niezmiernie istotna. Podróże terrorystyczne są oczywiście zakonspirowane i mają na celu utrzymanie utajnionych sieci chrakteryzujących światowy terroryzm. Sieci te posiadają zdolności taktyczne, narzędzia strategiczne do fałszowania dokumentów, zdolności do transgranicznej wymiany osób i ich przemieszczania. Szczegółowe szkolenie zwolenników, a także działaczy oraz zakonspirowanych sympatyków jest wstępnym warunkiem istnienia i działania organizacji terrorystycznej. Rekrutacja stanowi swoisty kompromis pomiędzy osobistą wiarą a brutalnym aktywizmem. Liczba podmiotów, jakie można zmobilizować do sieci terrorystycznej, zależy od sukcesu rekrutacji aktywistów i cichych zwolenników. Aktywiści są niezbędni do przetrwania organizacji. Do ich zadań należy zbieranie pieniędzy, logistyka czy komunikacja. Cisi zwolennicy lub agenci są właściwie przeszkoleni od razu po rekrutacji i następnie kierowani do przeprowadzenia prawdziwych ataków terrorystycznych.

Wiele dzisiejszych założeń oraz dowodów wskazuje, że lokalne komórki z reguły rozwijają się wokół krewnych czy przyjaciół, zwyczajowo inspirowane przez miejscowych przewodników duchowych bądź mentorów, a następnie są radykalizowane poprzez propagandę

${ }^{8}$ EUROPOL, Changes in Modus Operandi of Islamic State Revisited, http://www.EUROPOL.europa.eu/publications-documents/changesin,modus-operandi-of-islamic-state-revisited (dostęp: 21 VIII 2020).

${ }^{9}$ Ustawa z dnia 6 IV 1990 r. o Policji (tekst jedn. Dz.U. 2017, poz. 2067).

${ }^{10}$ Ustawa z dnia 24 VIII 2001 r. o Żandarmerii Wojskowej i wojskowych organach porządkowych (tekst jedn. Dz.U. 2016, poz. 1483 ze zm.).

${ }^{11}$ A. Molnar, op. cit., s. 135. 
prowadzoną w Internecie. Grupy terrorystyczne usiłują zgromadzić w swoich szeregach jak najwięcej agentów ukrytych w pobliżu istotnych elit przemysłowych, gospodarczych, a nawet w organach bezpieczeństwa zwalczanego państwa, których pomoc znacznie zwiększa prawdopodobieństwo powodzenia misji. Najbardziej popularne organizacje terrorystyczne, jak Daesh czy Al-Qaeda, zmieniły schemat swojej rekrutacji i obecnie rekrutują wśród młodzieży ze Stanów Zjednoczonej, Kanady i wielu krajów zachodnioeuropejskich. Wierza, że nowi rekruci mogą bezproblemowo przejść przez wszelkie inspekcje oraz kontrole na granicy państw, jednocześnie prowadząc skuteczną działalność operacyjną dla organizacji poprzez swoje kontakty i lokalną wiedzę.

Sieci terrorystyczne, począwszy od ich najniższych struktur, działają na podstawie specyficznie zakonspirowanej komunikacji ${ }^{12}$. Celem tych sieci i komórek jest przekazywanie między sobą informacji strategicznych, taktycznych i operacyjnych. Każdorazowo organizacja terrorystyczna, która wykracza poza swoją jurysdykcję miejscowa, zwraca szczególną uwagę na bezpieczną komunikację. Komunikacja taka jest ściśle tajna, lakoniczna i terminowa. W tym celu często wykorzystywane są usługi publiczne, ale utajnione dane są transportowane przez sprawdzonych posłańców. Doręczyciele wiadomości przekazują informację z pamięci, wykluczając fizyczną oraz techniczną formę rozpoznania. Takie osoby są również we właściwy sposób chronione i ukrywane przy użyciu właściwych dokumentów, które dają stosowne alibi osobie ich używającej. Są to osoby wybierane ze względu na ich wiarygodność i oddanie sprawie organizacji.

Organizacje terrorystyczne zwyczajowo zbieraja, gromadzą oraz uwierzytelniają zgromadzone pieniądze, by finansować ich rozległe sieci, komórki i pomocników. Znaczne środki są wydawane także na podróże, co wynika z zakupu wysokiej jakości prawdziwych lub fałszywych dokumentów. Organizacje terrorystyczne, podobnie jak zwykłe organizacje pożytku publicznego, zbierają prywatne darowizny z różnych źródeł legalnych, ale w tym przypadku również nielegalnych ${ }^{13}$. Ekstremistyczne, islamskie grupy terrorystyczne próbują czerpać korzyści z charytatywnych działań muzułmanów w celu otrzymywania darowizn. Uzyskują w ten sposób bezpośredni dostęp do finansów poprzez instytucje religijne bądź krajowe organizacje kulturalne. Grupy

${ }^{12}$ M. Rudner, Misure of Passports: Identity Fraud, the Propensity of Travel, and International Terrorism, "Studies in Conflict \& Terrorism” 2008, no. 31(2), s. 95-110.

${ }^{13}$ A. Molnar, op. cit., s. 136. 
terrorystyczne, żeby jeszcze bardziej zwiększyć swoje dochody, posuwają się do popełniania przestępstw. Reasumując, środki finansowe takich organizacji moga pochodzić z różnych źródeł legalnych (jak w organizacjach non profit czy organizacjach pomocy publicznej) bądź z nielegalnego handlu czy przestępczości zorganizowanej. Należy zauważyć, że działalność organizacji terrorystycznej w wielu aspektach jest podobna do działalności profesjonalnych, międzynarodowych grup przestępczych. Uzupełniają one swoje zasoby finansowe w sposób tradycyjny, pod płaszczem legalności, ale też wspierają swoje działania klasycznymi działaniami przestępczymi ${ }^{14}$.

W związku z tym, że zarówno przestępczość zorganizowana, jak i terrorystyczna jest karana w większości państw, poszczególne grupy wypracowały sposoby uwierzytelniania zdobytych środków, w tym operacji bankowych oraz przepływu produktów. System Hawala jest popularnym i nieformalnym systemem transferu wartości opartym nie na przepływie gotówki ani telegrafie lub przepływie przez sieć komputerową pomiędzy bankami, lecz na działaniu i honorze ogromnej sieci pośredników finansowych. Hawala jest tradycyjna w świecie arabskim, jest także używana w ramach transakcji handlowych preferujących towary o znacznej wartości, które w prosty sposób mogą zostać zamienione na gotówkę, np. diamenty albo inne kamienie szlachetne ${ }^{15}$. $\mathrm{W}$ przeciwieństwie do konwencjonalnego systemu bankowego zasady islamu pozwalają tylko na przepływ pieniądza do procesów, w których pieniądz nie zarabia, ale wytwarza towary. Organizacje terrorystyczne z reguły zlecają swoim wysłannikom transport gotówki lub innych aktywów w miejsce, gdzie organizacja w danym momencie ich potrzebuje.

Pozyskiwanie podstawowych materiałów do działalności, broni palnej, materiałów wybuchowych, dokumentów podróży i innego specjalistycznego wyposażenia jest fundamentem funkcjonowania terrorystów. Organizacje terrorystyczne w razie braku zwyczajowego zaplecza przemysłowego zmuszone są do szukania i pozyskiwania zasobów w alternatywny sposób ${ }^{16}$. Najważniejsze narzędzia zdobywa się w sposób

${ }^{14}$ P. Pomianowski, E. Maćkowiak, Zwalczanie finansowania terroryzmu w świetle prawa obowiązującego w Polsce i we Francji, „Przegląd Bezpieczeństwa Wewnętrznego” 2012, nr 6(4), s. 71-94.

${ }^{15}$ P.M. Jost, H.S. Sandhu, The Hawala Alternative Remittance System and its Role in Money Laundering, http://www.treasury.gov/resource-center/terrorist-illicit-finance/ Documents/FinCEN-Hawala-rpt.pdf (dostęp: 21 VIII 2020).

${ }^{16}$ A. Molnar, op. cit., s. 137. 
niejawny. Konspiracja organizacji terrorystycznych obowiązuje na każdym etapie. Pozyskiwanie w wolnym handlu chemikaliów bądź innych surowców daje gwarancję tajności, ponieważ przy właściwym połączeniu produktów łatwo dostępnych w każdym sklepie można stworzyć niebezpieczną broń. Dlatego też podróżowanie jest bardzo istotnym tematem związanym z zakupami dokonywanymi przez grupy terrorystyczne. Znanych jest wiele przypadków przemieszczania się przez określone osoby po wielu krajach i kontynentach w celu pozyskiwania materiałów wybuchowych, sprzętu i innych akcesoriów.

Prawdopodobna jest teoria, że grupy terrorystyczne rekrutują swoich członków na uczelniach i w instytucjach badawczych różnych państw w celu wykonania zadań związanych z określoną wiedzą laboratoryjna, ale także wykonania zadań w sposób tajny, związanych z produkcją materiałów do działalności organizacji. Aby wzmocnić jeszcze bardziej działalność współczesnych sieci terrorystycznych, miejsca te muszą funkcjonować jednocześnie jako ośrodki rekrutacji. Terroryści wzmacniają swoje zdolności operacyjne i wykonawcze w dziedzinie finansów, informatyki, chemii, biologii, transportu lotniczego, samochodowego i kolejowego. Wszystko to przypomina spójność przedsiębiorstwa.

Konspiracyjny charakter wzmacnia tajna migracja i tworzenie ukrytych lokalizacji, w których prowadzone są potajemne przygotowania i szkolenia. Nie ma jednego typowego kraju tworzenia danych lokalizacji. Takie obozy są tworzone na całym świecie i są ściśle ukrywane. Poszczególne lokalizacje stanowią bezpieczne domy lub komórki sypialniane. Są miejscami przyjęcia członka realizującego określoną misję albo planowania kolejnych misji. Komórki mieszkalne służą jako schronienie dla członków organizacji po przekroczeniu granicy w sposób legalny lub nielegalny. Istnieje wiele takich bezpiecznych domów i schronień w różnych miastach o różnym zaludnieniu, utrzymywanych przez międzynarodowe sieci terrorystyczne. Są one starannie dobierane, każdorazowo pod kątem planowanej misji, co zmniejsza możliwość dekonspiracji i upadku zadania. Działalność terrorystów w tym aspekcie bardzo przypomina działanie tajnych służb wywiadowczych, ale również drobnych, partyzanckich organizacji bojowych.

Planowanie i przygotowanie określonego działania jest najbardziej czasochłonne, gdyż sukces misji zależy od jakości wykonania planu w najmniejszych szczegółach. Pierwszym etapem planu jest odnalezienie miejsc z dużą liczbą przypadkowych zmian. Takie przypadki z reguły wywołują panikę wśród ludzi i co najważniejsze - zdarzenia zaistniałe 
w danych miejscach będą relacjonowane w środkach masowego przekazu. Następnym krokiem, po wyborze optymalnego miejsca docelowego, jest opracowanie przez kierownictwo organizacji szczegółowego planu zamachu terrorystycznego. Jednocześnie sprawdza się, czy osoby wskazane do wykonania misji są właściwie przeszkolone oraz szczegółowo poinformowane o zakresie ich zadań i o niezbędnych materiałach, które otrzymaja, np. paszportach ${ }^{17}$. Niekiedy terroryści podróżują również z prawdziwymi dokumentami, lecz nielegalnie uzyskane, kradzione, wynajęte, zakupione puste dokumenty, sfałszowane dokumenty lub dokumenty wydane przez półlegalne biura obszarów kryzysowych dają terrorystom możliwość działania w konspiracji i stworzenia strategicznej niespodzianki.

Dokumenty czy paszporty, zwłaszcza pozornie prawdziwe, są wyjątkowo cenne dla międzynarodowych grup terrorystycznych i przestępczych. Członkowie grupy wyznaczeni do większej liczby zadań mogą posiadać nawet więcej niż jeden dokument tożsamości. Jednakże istnieje pewna zwyczajowa zasada, że podróżujący z podrobionym lub sfałszowanym dokumentem nie może wjechać do kraju z dokumentami wydanymi przez ten konkretny kraj. W innym wypadku korzystanie z danego nielegalnego dokumentu może bardzo szybko zostać wykryte. Są kraje, których paszporty i inne dokumenty podróży są bardzo faworyzowane przez grupy terrorystyczne, np. dokumenty krajów wielokulturowych, jak Francja czy Niemcy, których ludność jest niejednorodna pod względem demograficznym i religijnym, w których podróżowanie obywateli odbywa się znacznie częściej niż w innych krajach oraz których dokumenty są bardziej znane wśród światowej straży granicznej i innych służb bezpieczeństwa. Nie bez znaczenia jest fascynacja określonymi dokumentami: wiąże się to z faktem, że osoba podróżująca z takim dokumentem korzysta $\mathrm{z}$ bezwizowego wjazdu do wielu krajów na świecie, kontrola jest mniej dokładna, zwrócona jest na takie osoby mniejsza uwaga. Po przekroczeniu strefy Schengen terroryści mogą swobodnie i bezproblemowo przemieszczać się pomiędzy krajami członkowskimi Unii Europejskiej. Ze względu na nowoczesne zabezpieczenia paszporty i inne współczesne dokumenty podróży są kosztowne i trudne do sfałszowania. Wcześniej skradzione dokumenty nie tracą na wartości i są nadal użyteczne. Podmiot korzystający z nich ma duże szanse przejścia przez granicę, a w razie dekonspiracji nie

${ }^{17}$ A. Molnar, op. cit., s. 138. 
ponosi poważnych konsekwencji, chyba że został zidentyfikowany jako terrorysta. Wówczas służby mogą odmówić przyjęcia osoby, zawrócić ją lub skonfiskować dokumenty, ale także uznać daną działalności za przestępstwo ${ }^{18}$.

\section{Wyzwania na rzecz współczesnego bezpieczeństwa}

Międzynarodowe wysiłki na rzecz zwalczania przestępczości terrorystycznej i przestępstw im towarzyszących obejmuje rozszerzenie współpracy międzyrządowej, zwiększenie bezpieczeństwa dokumentów w aspekcie zabezpieczeń i biometrii w paszportach oraz dokumentach podróży wydawanych przez państwa wspólnoty europejskiej, a także zwiększenia aktywności służb kontroli granicznej. Kolejnym i niezbędnym aspektem jest poszerzenie współpracy i przyjęcie międzynarodowych konwencji antyterrorystycznych, które będą właściwie przystosowywane i nowelizowane do przeciwdziałania coraz to nowszym działaniom terrorystów. Dobrym tego przykładem może być wejście nowych przepisów o działaniach antyterrorystycznych w Polsce, które zwiększyły uprawnienia operacyjne służb specjalnych ${ }^{19}$, w szczególności Agencji Bezpieczeństwa Wewnętrznego i Agencji Wywiadu ${ }^{20}$, ale także Służby Kontrwywiadu Wojskowego i Służby Wywiadu Wojskowego ${ }^{21}$.

W chwili obecnej istnieją dziesiątki miejsc objętych konfliktem zbrojnym, miejsc zaś, gdzie stosowane są brutalne okrucieństwa, a ludność zmuszana jest do uchodźstwa, jest jeszcze więcej. Praktycznie na każdym kontynencie znajdują się niestabilne kraje, w których ludność jest dotknięta przemocą i niepewnością. W konfliktach o niskiej intensywności największe zagrożenie stanowią osoby przemieszczające się w przebraniu, ponieważ tłumy uchodźców uciekających ze stref kryzysowych muszą być traktowane jako niemożliwa w praktyce do zidentyfikowania masa. W większości krajów nie ma bazy danych, która w sposób niezawodny dawałaby szansę rozeznania się w osobach chcących przekroczyć granice państw wolnych od brutalnych konfliktów.

\footnotetext{
${ }_{18}^{18}$ A. Molnar, op. cit., s. 139.

${ }^{19}$ Ustawa z dnia 10 VI 2016 r. o działaniach antyterrorystycznych (Dz.U. 2016, poz. 904 ze zm.).

${ }^{20}$ Ustawa z dnia 24 V 2002 r. o Agencji Bezpieczeństwa Wewnętrznego oraz Agencji Wywiadu (Dz.U. 2016, poz. 1897).

${ }^{21}$ Ustawa z dnia 9 VI 2006 r. o Służbie Kontrwywiadu Wojskowego oraz Służbie Wywiadu Wojskowego (Dz.U. 2017, poz. 1879).
} 
Konieczny jest rozwój, współpraca na arenie międzynarodowej, możność pomocy tym najbardziej dotkniętym prześladowaniami, a przede wszystkim oddzielenia ich od tych, którzy korzystają na bezmyślnym oraz nieprofesjonalnym udzielaniu pomocy w celu szerzenia jeszcze większego terroru i chaosu ${ }^{22}$.

Problem stanowi nie tylko wjazd terrorystów, ale również odpływ kandydatów na bojowników, utożsamiających się z ekstremistycznymi poglądami terrorystów. Konsekwencją tego jest działalność właściwych organów krajowych w celu zablokowania podróży międzypaństwowych na granicach, ale też zapobieżenia rozprzestrzeniania się ideologii drogą radiową. Konieczne jest blokowanie, usuwanie wszelkich treści rozpowszechniających zaproszenia oraz informacje na stronach mediów społecznościach, które mogą dotyczyć rekrutacji do organizacji terrorystycznych. Niezbędne jest ponadto odnajdywanie ludzi z rozwiniętych krajów Ameryki i Europy, którzy mają zamiar udać się do miejsc objętych kryzysem w celu dołączenia do operacji lub działań ekstremistycznych organizacji terrorystycznych. Konieczne jest ograniczenie mobilności takich osób, jest to jednak sporym wyzwaniem i obowiązkiem na poziomie krajowym. W dobie coraz częstszych aktów terrorystycznych na świecie, a przede wszystkim w państwach Unii Europejskiej, niezaprzeczalny jest fakt, że służby muszą bezwzględnie zapobiegać bezprawnym aktom terroryzmu i stosować kontrolę prewencyjną. Warunkiem koniecznym jest zwiększenie wewnętrznego poczucia bezpieczeństwa ludzi przez uzasadnienie masowych kontroli stosowanych w celu ochrony.

Obywatele państw wspólnotowych nie są świadomi procesów odbywających się wokół. Niewątpliwie uzasadniona, legalna i wciąż rozwijana jest kontrola urzędowa nieustannego rozwoju międzynarodowych organizacji przestępczych i terrorystycznych, a także związanych z nimi przestępstw fałszowania dokumentów. Państwa Unii Europejskiej mają obowiązek zapewnić bezpieczeństwo obywateli przy zachowaniu prawa do swobodnego przemieszczania się i praktycznie nieograniczonego pobytu. Największy problem stanowi to, że swobodny przepływ towarów, usług, kapitału i ludzi jest jedną z najważniejszych wartości integracyjnych Unii Europejskiej, a jednocześnie daje nieograniczone możliwości migracji terrorystycznej. Paradoks ten należy do głównych problemów dotyczących kryzysu wartości Unii Europejskiej. Odnosi

${ }^{22}$ J. Kis-Bendek, op. cit., s. 11. 
się do wyboru pomiędzy ograniczeniem przepływu ludzi wewnątrz państw członkowskich i jednoczesną degradacją integracji europejskiej przy zwiększeniu bezpieczeństwa wspólnotowego a nieskrępowanym przemieszczaniem się, większą integracją państw członkowskich, ale także zwiększonym ryzykiem migracji terrorystycznej ${ }^{23}$.

Większość aktów terrorystycznych w minionych latach ukazuje, że szwankuje nie tyle słabo rozwinięta kontrola na granicach Unii Europejskiej, co komunikacja, współpraca i wymiana informacji pomiędzy służbami poszczególnych państw członkowskich ${ }^{24}$. Brak właściwego przepływu informacji może być surowo krytykowany, ponieważ niejednokrotnie doprowadzało to do skutecznie przeprowadzonego zamachu terrorystycznego. Jawne raporty wskazują, że personalia żywych bądź zmarłych osób zostały wykorzystane do stworzenia legalnych dokumentów podróży dla osób podających się za uchodźców, a faktycznie będących członkami grypy terrorystycznej, która próbowała przedostać się do Europy legalną drogą ${ }^{25}$.

Współcześnie zauważa się, że wśród terrorystów ideologia religijna stała się o wiele istotniejsza niż dotychczas, ważniejsza nawet od samej organizacji. Główne grupy islamskie nie podlegają żadnym wpływom zewnętrznym, politycznym granicom i zasadom cechującym państwa demokratyczne. Nie ponoszą odpowiedzialności za swoje działania. Grupy terrorystyczne mają charakter autonomiczny, są nieprzewidywalne oraz działają na wysokim stopniu inicjatywy i konspiracji ${ }^{26}$.

\section{Podsumowanie}

Definicja bezpieczeństwa bez względu na czas i politykę winna być precyzyjna i uniwersalna, określać stan gwarantujący każdej jednostce społecznej przede wszystkim pewność istnienia oraz przetrwania ${ }^{27}$.

${ }^{23}$ Z. Hautzinger, A terrorizmus elleni kuzdelem idegenjogi eszkozei, Modernkori veszelyek rendeszeti aspektusai, Pecs: Pecsi Hataror Tudomanyos Kozlemenyek XVI, Budapest 2015, s. 205.

${ }^{24}$ A. Molnar, op. cit., s. 141.

${ }^{25}$ The mystery surrounding the Paris bomber with a fake Syrian passport, "The Washington Post", http://washingtonpost.com/world/europe/the-mystery-surrounding-the-paris-bomber-with-a-fake-syrian-passport/2015/11/17/88adf3f4-8d53-11e5-934c-a369c80822c2_story.html?noredirect=on (dostęp: 21 VIII 2020).

${ }^{26}$ J. Kis-Bendek, op. cit., s. 158.

${ }^{27}$ P. Majer, W poszukiwaniu uniwersalnej definicji bezpieczeństwa wewnętrznego, „Przegląd Bezpieczeństwa Wewnętrznego" 2012, nr 7(4), s. 11. 
Współczesna walka z terroryzmem nie będzie miała miejsca na odległych od obszarów zamieszkania polach bitewnych obszarów kryzysowych, lecz na obszarach chronionych, w państwach rozwiniętych. Zasadniczym zadaniem współczesnych państw prawa jest właściwe egzekwowanie prawa oraz skuteczna działalność wywiadowczych i kontrwywiadowczych służb specjalnych. Bezwzględnie potrzebna jest właściwa i specjalistyczna wiedza zawodowa funkcjonariuszy służb specjalnych oraz kontroli granicznej, posiadanie szybkich i istotnych informacji w ramach współpracy międzynarodowej, nowoczesne zaplecze informatyczne i techniczne ${ }^{28}$.

Należy podkreślić fakt, że do rozwiązania sporu wartości oraz usunięcia groźnych postaw członków wspólnoty europejskiej niezbędna jest profesjonalna i nowoczesna działalność organów ścigania, służb specjalnych i granicznych. Działalność ta musi być poparta nie tylko skrupulatną pracą na szczeblu krajowym, ale także na arenie międzynarodowej. Wyłącznie otwarty przepływ informacji i profesjonalna współpraca służb na szczeblu międzynarodowym umożliwią zahamowanie nowoczesnej migracji terrorystycznej, zachowanie pierwotnych wartości wspólnotowych oraz nieograniczoną pomoc osobom uciekającym z obszarów kryzysowych lub przyjęcie emigrantów zarobkowych, którzy wzbogacają kulturowo i nie niszczą porządku oraz bezpieczeństwa państwa otwartego na emigrację $e^{29}$.

Współczesny terroryzm jest zjawiskiem globalnym i wciąż rozwijającym się. Terroryzm pojawia się najczęściej w krajach rozwiniętych i w strefach kryzysowych. Skuteczne prowadzenie działań terrorystycznych, ataków terrorystycznych czy transakcji jest efektem umiejętnego przemieszczania się w sposób elastyczny, ale też właściwego ukrywania się na obcym dla terrorysty obszarze. Organizacje terrorystyczne zmierzają do budowy profesjonalnej struktury o rozbudowanej administracji finansowej, z nowoczesnym systemem rekrutacji nowych członków, w celu zapewnienia przyszłości grupy. Do tego niezbędne jest umiejętne wprowadzanie w błąd władz państw, z którymi organizacja walczy, poprzez dostęp do najnowszych technologii, nowoczesny system planowania oraz dostęp do dokumentów podróży jako tych, które stanowią podstawę działania dywersyjnego, sabotażowego lub wywiadowczego na terytorium wroga organizacji. Stąd też niezwykle ważne jest, aby

${ }^{28}$ Z. Szekely, Application of Robotics for Enhanced Security: European Research on Security Robots, Budapest 2014, s. 139.

${ }^{29}$ A. Molnar, op. cit., s. 142. 
obserwować nie tylko wszystkich członków, ale i potencjalnych rekrutów do grup terrorystycznych. Tylko ten sposób pozwoli na szybkie dostrzeżenie nielegalnego wykorzystania dokumentów podróży.

Migracja terrorystyczna jest podstawowym i niezbędnym krokiem w stronę działań terrorystycznych, a do tego konieczne są profesjonalne dokumenty podróży. Są one potrzebne na wstępnym etapie ataku, ale również w kolejnych etapach; są istotne w takim samym stopniu co broń lub materiały wybuchowe. Nielegalne zastosowanie dokumentów podróży daje możliwość nieskrępowanego przemieszczania się, ukrywania celu, trasy oraz działalności. Dokumenty podróży takie jak paszport są jedyną bronią terrorystów w razie konfrontacji z punktem kontrolnym na granicy. Punkt graniczny jest $\mathrm{z}$ reguły głównym miejscem wykrywania nielegalnej migracji. Wyłącznie profesjonalna współpraca służb, nowoczesny system weryfikacji i zabezpieczania dadzą szansę ochrony przed nielegalnym zagrożeniem bezpieczeństwa.

Mimo nowoczesnej i rozwijającej się działalności organizacji terrorystycznych istnieje droga do powstrzymania ekstremistycznych ruchów terrorystycznych i pomocy obszarom kryzysowym. Kluczem jest nowoczesna i profesjonalna współpraca międzynarodowa, ale także legalna działalność prewencyjna i kontrolna. Dzięki nim możliwe jest zażegnanie kryzysu wartości państw Unii Europejskiej, co da szansę na dalszy rozwój wspólnotowy i międzynarodowy.

\section{THE IMPACT OF MODERN TERRORISM MIGRATION ON SECURITY}

\section{Su m mary}

The premise of this text is to analyze by means of selected examples the issues related to the broad definition of security, and modern and developing terrorist migration. Moreover, the aim of this paper is to approach the subject in question from the perspective of the current legal state by means of the formal and dogmatic method, but also by means of the method of criticism and analysis of the literature, which will allow a full understanding of the shape, functioning and causes of errors of modern security bodies. The above will influence the formulation of de lege ferenda postulates in the conclusion. The European Union is based on solid foundations. So how does globalisation, in its broadest sense, affect the world around us and the elementary values of the modern world? Modern terrorism, which strikes at the security of developed countries, is undoubtedly a global phenomenon that also sows fear for normal existence in one's own country. Unrestricted, cross-border terrorist activity is leading to intra-community division. This is the result of internal conflicts over common values. The surveillance and detection of migrants from 
outside the European community who are criminals is becoming a more difficult task with time. This is due to the fact that terrorist organisations operate according to a well-defined plan, creating extensive networks and recruiting new members for their groups in many countries simultaneously. The fight against terrorism is being waged on Europe's streets and in the homes and schools of its citizens. The struggle for security begins at the borders of European countries. What is crucial in this fight is the latest equipment and cooperation between security bodies, including the special services of all the countries of the European Union and NATO. It is essential to introduce appropriate legislation to limit the free movement of people who commit crimes and to develop methods to distinguish terrorists from economic migrants or refugees. The state must guarantee the security of its citizens and combat terrorism effectively.

Keywords: terrorism - globalisation - travel - document - control

\section{LITERATURA}

EUROPOL, Changes in Modus Operandi of Islamic State Revisited, http://www.EUROPOL.europa.eu/publications-documents/changesin,modus-operandi-of-islamic-state-revisited (dostęp: 21 VIII 2020).

Faiola A., The mystery surrounding the Paris bomber with a fake Syrian passport, "The Washington Post", http://washingtonpost.com/world/europe/the-mystery-surrounding-the-paris-bomber-with-a-fake-syrian-passport/2015/11/17/88adf3f4-8d53-11e5-934c-a369c80822c2_story.html?noredirect=on （dostęp: 21 VIII 2020).

Freud S., Das Unbehagen in der Kultur, w: idem, Kulturtheoretische Schriften, Frankfurt a. Main 1974.

Hautzinger Z., A terrorizmus elleni kuzdelem idegenjogi eszkozei, Modernkori veszelyek rendeszeti aspektusai, Pecs: Pecsi Hataror Tudomanyos Kozlemenyek XVI, Budapest 2015.

Jost P.M., Sandhu H.S., The Hawala Alternative Remittance System and its Role in Money Laundering, http://www.treasury.gov/resource-center/terrorist-illicit-finance/Documents/FinCEN-Hawala-rpt.pdf (dostęp: 21 VIII 2020).

Kis-Bendek J., Dzihadizmus, Radikalizmus, Terrorizmus, Budapest 2016.

Majer P., W poszukiwaniu uniwersalnej definicji bezpieczeństwa wewnętrznego, „Przegląd Bezpieczeństwa Wewnętrznego" 2012, nr 7(4).

Molnar A., Travel Documents in Use by Terrorists, "Internal Security” 2019, no. 11(1).

Piekarski M., Ewolucja taktyki terrorystów po roku 2001, „Przegląd Bezpieczeństwa Wewnętrznego" 2015, nr 13(7).

Pomianowski P., Maćkowiak E., Zwalczanie finansowania terroryzmu w świetle prawa obowiązujacego w Polsce i we Francji, „Przegląd Bezpieczeństwa Wewnętrznego” 2012, nr 6(4).

Rudner M., Misure of Passports: Identity Fraud, the Propensity of Travel, and International Terrorism, "Studies in Conflict \& Terrorism” 2008, no. 31(2). 
Sulowski S., W poszukiwaniu definicji bezpieczeństwa wewnętrznego, „Przegląd Bezpieczeństwa Wewnętrznego" 2009, nr 1.

Szekely Z., Application of Robotics for Enhanced Security: European Research on Security Robots, Budapest 2014.

Vajda A., Kuzdelem a terrorizmus ellen, Budapest 2003.

Wojciechowski S., Terroryzm. Analiza pojęcia, „Przegląd Bezpieczeństwa Wewnętrznego" 2009, nr 1. 


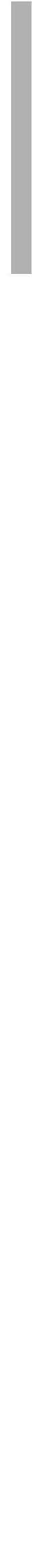

